\title{
Validation of TRMM and FEWS Satellite Rainfall Estimates with Rain Gauge Measurement over Ashanti Region, Ghana
}

\author{
Leonard K. Amekudzi1 ${ }^{*}$, Marian A. Osei ${ }^{1}$, Winifred A. Atiah ${ }^{1}$, Jeffrey N. A. Aryee ${ }^{1}$, \\ Maureen A. Ahiataku1,2, Emmanuel Quansah1, Kwasi Preko', Sylvester K. Danuor ${ }^{1}$, Andreas H. Fink ${ }^{3}$ \\ ${ }^{1}$ Meteorology and Climate Science Unit, Department of Physics, Kwame Nkrumah University of Science and Technology, Kumasi, Ghana \\ ${ }^{2}$ Ghana Meteorological Agency, Accra, Ghana \\ ${ }^{3}$ Karlsruhe Institute of Technology (KIT), Institute of Meteorology and Climate Research, Karlsruhe, Germany \\ Email: *lkamekudzi.cos@knust.edu.gh
}

How to cite this paper: Amekudzi, L.K., Osei, M.A., Atiah, W.A., Aryee, J.N.A., Ahiataku, M.A., Quansah, E., Preko, K., Danuor, S.K. and Fink, A.H. (2016) Validation of TRMM and FEWS Satellite Rainfall Estimates with Rain Gauge Measurement over Ashanti Region, Ghana. Atmospheric and Climate Sciences, 6, 500-518. http://dx.doi.org/10.4236/acs.2016.64040

Received: August 22, 2016

Accepted: October 25, 2016

Published: October 28, 2016

Copyright $\odot 2016$ by authors and Scientific Research Publishing Inc. This work is licensed under the Creative Commons Attribution International License (CC BY 4.0).

http://creativecommons.org/licenses/by/4.0/

(c) (i) Open Access

\section{Abstract}

Satellite rainfall estimates have predominantly been used for climate impact studies due to poor rain gauge network in sub-Saharan Africa. However, there are limited microscale studies within the sub-region that have assessed the performance of these satellite products, which is the focus of the present study. This paper therefore considers validation of Tropical Rainfall Measuring Mission (TRMM) and Famine Early Warning System (FEWS) satellite estimates with rain gauge measurements over Ashanti region of Ghana. First, a consistency assessment of the two gauge data products, the Automatic Rain Gauge (ARG) and Ghana Meteorological Agency (GMet) Standard Rain Gauge (SRG) measurements, was performed. This showed a very good agreement with correlation coefficient of 0.99 . Secondly, satellite rainfall products from TRMM and FEWS were validated with the two gauge measurements. Validation results showed good agreement with correlation coefficients of 0.6 and 0.7 for TRMM and FEWS with SRG, and 0.87 and 0.86 for TRMM and FEWS with ARG respectively. Probability Of Detection (POD) and Volumetric Hit Index (VHI) were found to be greater than 0.9. Volumetric Critical Success Index (VCSI) was 0.9 and 0.8 for TRMM and FEWS respectively with low False Alarm Ratio (FAR) and insignificant Volumetric Miss Index (VMI). In general, relatively low biases and RMSE values were observed. The biases were less than 1.3 and 0.8 for TRMM and FEWSRFE respectively. These indicate high rainfall detection capabilities of both satellite products. In addition, both TRMM and FEWS were able to capture the onset, peak and cessation of the rainy season, as well as the dry spells. Although TRMM and FEWS sometimes under/overestimated rainfall, they have the potential to be used for agricultural and other hydro-climatic impact studies over the region. The Dynamic- 
Aerosol-Cloud-Chemistry Interactions in West Africa (DACCIWA) project will provide an improved spatial gauge network database over the study area to enhance future validation and other climate impact studies.

\section{Keywords}

Rain Gauge, Validation, TRMM and FEWS-RFE, DACCIWA Project, Ashanti Region

\section{Introduction}

Rainfall is the primary driver of the hydrologic cycle and the main input for hydro meteorological models and climate studies [1]. It is an essential resource for socioeconomic activities especially for developing countries that rely solely on rain-fed agriculture [2]. Variations in rainfall totals could have negative implications for rainfall dependent agriculture. In general, rainfall exhibits inter-annual and multi-decadal variability in West Africa [3] [4]. Several studies have shown a downward trend in rainfall for the period 1970 - 2000 ([5], and also references therein). However, there have been signs of recovery in the 2000s [4] [5].

The high limitation of rain gauges and weather radar systems, especially, in the tropics, reiterated the importance of satellite-based global rainfall data for weather and climate studies [1], hence the operation of the Tropical Rainfall Measuring Mission (TRMM) and Famine Early Warning System (FEWS). TRMM's launching has provided optimum understanding and synchronous measurements of rainfall and radiative fluxes in the tropics and subtropics [6]. FEWS Rainfall Estimate (FEWS-RFE), on the other hand, is operated by the United States Agency for International Development (USAID) to assist in drought monitoring efforts for Africa [7] [8]. The FEWS-RFE, due to its high spatial resolution $\left(0.1^{\circ} \times 0.1^{\circ}\right)$, has the ability to blend gauge and satellite information on near-real time basis to provide rainfall estimates over Africa [8].

Rigorous validation has been carried out by comparing in-situ measurements with TRMM satellite estimates, for example [3] [9] [10]. These studies have improved our understanding of spatio-temporal variations of rainfall in the tropics. Some studies have shown under/over estimation of TRMM estimates over gauge while using either version 6 (V6) or 7 (V7) with a spatial resolution of $0.25^{\circ} \times 0.25^{\circ}$ and a 3-hour temporal resolution [3] [11] [12] [13] [14]. Nicholson et al. (2003) [3] validated preTRMM and the blended rainfall products, Geostationary Operational Environmental Satellite (GOES) Precipitation Index (GPI), and the Global Precipitation Climatology Project (GPCP) version 1, and found inadequacies in pre-TRMM satellite rainfall analyses over Africa. Nonetheless, they indicated that the product proved very useful for climatological studies if tactfully interpreted. Young et al. (2014) [15] studied two standards of TRMM Multisatellite Precipitation Analysis (TMPA) products, 3B42 real time (3B42RT) and 3B42 version 6 (3B42V6), which were quantitatively evaluated in 
the Laohahe basin, China over a 6-year period (2000-2005). They observed that the spatiotemporal rainfall characteristics were well captured by TMPA 3B42V6 estimates while 3B42RT estimates showed unrealistic overestimation throughout the year. Moreover, both RT and V6 satellite rainfall estimates were found to have a geotopography-dependent pattern. In areas of lower latitudes and elevations, better performance was observed for both RT and V6. Maggioni et al. (2016) [14] also found that TRMM 3B42 rainfall products had lower false alarm rate relative to other Satellite products.

Tompkins and Adebeyi [16] studied the relationship between cloud and rainfall changes from three products: TRMM, FEWS-RFE and Climate Prediction Center (CPC) morphing technique (CMORPH) over West Africa. They found that the TRMM rainfall estimates had a distinct maximum centred over the deep convective zone at $5^{\circ} \mathrm{N}$, with a secondary maximum at $10^{\circ}-12^{\circ} \mathrm{N}$. In addition, they observed that CMORPH overestimated rainfall in the northern zone, whereas FEWS-RFE and TRMM underestimated rainfall from intense convection systems over the $5^{\circ}-12^{\circ} \mathrm{N}$ zone. Similarly, slight disparities in heavy rainfall for FEWS-RFE estimates were observed by Symeonakis et al. (2008) [8].

In a related study, Moazami et al. (2013) [17] compared the Precipitation Estimation from Remotely Sensed Information by using Artificial Neural Networks (PERSIANN) and TRMM Multisatellite Precipitation Analysis (TMPA) version 7 precipitation products with rain gauge data over Iran. They observed that although PERSIANN exhibited better results in detecting rainfall events, it had a false alarm ratio which was worse than that of TRMM 3B42RT and 3B42V7 products. As-Syakur et al. (2011) [18] compared daily, monthly, and seasonal rain rates derived from TMPA with rain gauge over the Bali islands and observed good and poor agreements on monthly and daily scales respectively. The TRMM satellite estimates therefore have good potential for hydrological applications [19], intraseasonal studies [20] and consistency check of ground-based measurements [3] [9] [10] [11] [13].

In-country validation of satellites with gauge data has only been a handful in SubSaharan Africa; among the few are the studies by Haque et al. (2013) [21] over Tanzania, Friesen and Diekkrüger, 2002 [22] over Northern Ghana and Thiemig et al. (2012) [12] over Africa river basins including the Volta basin in Ghana and Burkina Faso. These studies found TRMM to perform quite well, but observed TRMM's difficulties in identifying squall line formations that could be associated with measured events on the ground [22] and high intensity rainfall periods [21]. FEWS-RFE is also observed to predict the frequency of rainfall and is especially useful for the assessment of dry spells over other satellite products such as Climate Hazards Group InfraRed Precipitation with Stations (CHIRPS) and TAMSAT African Rainfall Climatology and Time-series (TARCAT). In Ghana, there is sparse network of rain gauges, making the acquisition of rainfall data in some remote areas quite difficult. In addition, there has been a few validation publications on FEWS-RFE [23], hence its inclusion in this paper will be a valuable contribution. 
The main objective of this paper is to validate TRMM and FEWS satellite estimates with rain gauge measurements over the Ashanti region of Ghana. This paper will form a prelude to the DACCIWA (Dynamics-aerosol-chemistry-cloud interactions in West Africa) Work Package 6 validation studies over the Ashanti Region [24]. The paper is structured as follows: Section 2 presents the study site and data source. Methodology is presented in Section 3, while results and discussions are given in Section 4. Finally, Section 5 presents the conclusions.

\section{Study Site and Data}

\subsection{Study Site and Rain Gauge Dataset}

Ashanti region of Ghana was selected for this study, because the region serves as the DACCIWA Work Package Six (WP6) study site. Within this region there are nine existing GMet rainfall measurement stations, and data from these stations covering the period of 2001 to 2010 were used for the study. Furthermore, 4 years (2011-2014) rainfall data from automatic rain gauges deployed by the Meteorology and Climate Science Unit, Department of Physics, KNUST in collaboration with University of Cologne, Germany as part of Quantifying Weather and Climate Impacts on health in developing countries (QWeCI) project was also used for a pixel to pixel intercomparison. Figure 1 shows the study site, covering an area of $4338 \mathrm{~km}^{2}$ at elevation of 250 - $350 \mathrm{~m}$ above see level. The Ashanti region lies in the forest zone of Ghana where rainfall is strongly controlled by the West African Monsoon (WAM) and convective activities due to the movements of the Inter-tropical Discontinuity (ITD). The WAM is primarily driven by energy and temperature gradients between the Gulf of Guinea and the Sahara [25]. The maritime tropical air-mass originating from the Atlantic ocean is moisture laden and converges with the dry northeast continental tropical airmass along the ITD ([25] and also references therein). Spatial patterns of annual rainfall conforms to the south-north-south displacement of the ITD with a mean upward motion that reaches a pressure of $200 \mathrm{mb}$ [26]. Movement of the ITD results in a bi-modal rainfall pattern in the region. The onset of the rainy season occurs around the second to third dekad in March with maximum rains recorded in June. The minor season which is relatively short starts from first to second dekad of September and retreats in the second to third dekad of November [5] [25].

Rain gauges provide the ground truth of rainfall data [27] which can be used as a benchmark for comparison with satellite rainfall estimates. Data from two different rain gauge types were used, the standard rain gauge (SRG) used at GMet stations and the automatic rain gauges (ARG) used at $\mathrm{QWeCI}$ project sites. The automatic rain gauge used, works on the "weighing" principle. Thus, rainfall collected in a container is measured by an electronic weighing cell and stored in a data logger. The data stored is then downloaded via a software called HYDRAS 3 [28]. Based on its principle of operation and design, the instrument is able to measure rainfall intensity (rain rate), total rainfall amount and evaporation rate. The time resolution for the ARG measurements is 10 minutes. 


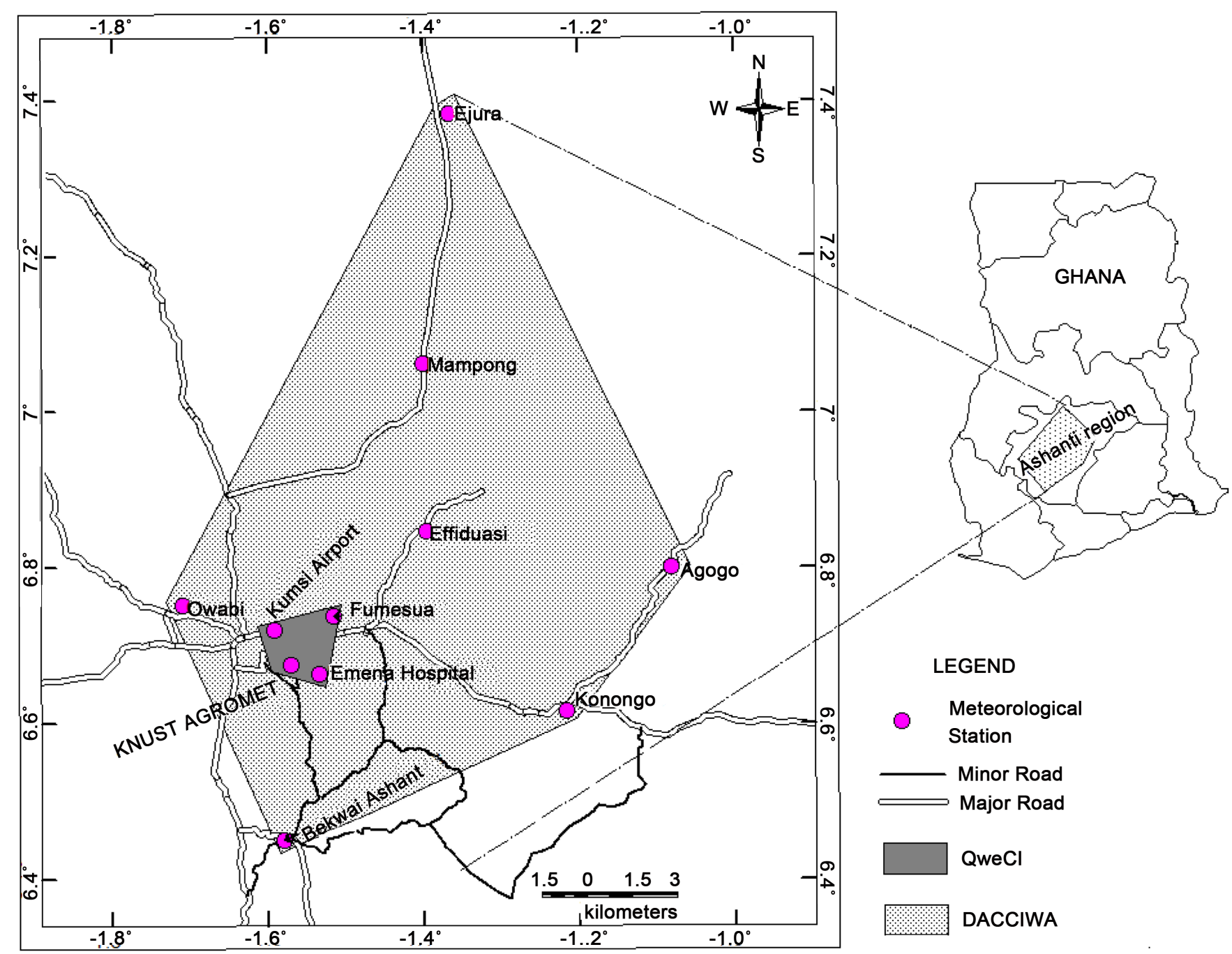

Figure 1. Location of rain gauges (violet circles), grey-shaded polygon is DACCIWA project coverage area in Ashanti region, Ghana.

\subsection{TRMM Dataset}

TRMM started operation in 1997, however, in this paper, version 7 (V7) daily data from 2001-2014 at a spatial resolution of $0.25^{\circ} \times 0.25^{\circ}$ were used. The three primary rainfall payloads on-board TRMM include; TRMM Microwave Imager (TMI), Precipitation Radar (PR) and Visible Infrared Scanner (VIRS). TMI gives quantitative rainfall information, PR provides three dimensional maps of storm structures and VIRS provides a link between derived rainfall using visible and infrared (IR) techniques [29]. A better resolution of PR $(215 \mathrm{~km})$ enables it to observe small scale rainfall features that otherwise cannot be unambiguously resolved by TMI which has a spatial resolution of $759 \mathrm{~km}$ ([9] and also references therein)

The post-real time TRMM/TRMM Multisatellite Precipitation Analysis (TMPA) 3B42 version 7 dataset, henceforth TMPA 3B42v7, at 3-hour interval was used for this study. The motivation of the $3 \mathrm{~B} 42$ algorithm is to produce TRMM and rain gaugeadjusted multisatellite rainfall rate and root-mean-square rainfall-error estimates [30]. 
The TMPA algorithm calibrates and combines microwave (MW) precipitaiton estimates and creates the infrared rainfall (IR) estimates using the calibrated MW ([31] and also references therein).

The MW input data were intercalibrated into TRMM Combined Instrument (TCI) rainfall estimates and IR estimates were computed using monthly microwave-IR histogram matching; this accounted for all the missing data in the individual 3-hourly merged-microwave fields in the IR estimates. The 3-hourly merged-microwave fields were then summed into monthly files and recombined with monthly accumulated Global Precipitation Climatology Centre (GPCC) rain gauge analysis to form a monthly best-estimate rainfall rate at a $0.25^{\circ} \times 0.25^{\circ}$ grid. Finally, $3 \mathrm{~B} 42$ rainfall $(\mathrm{mm} / \mathrm{hr})$ estimates are obtained by re-scaling the 3-hourly estimates ([15] [31] and also references therein).

\subsection{FEWS-RFE Dataset}

This paper also employed FEWS-RFE version 2 (v2.0) daily product from 2001 to 2014. The FEWS-RFE data is a blended product based on Cold Cloud Duration (CCD) derived from Meteosat Thermal InfraRed (TIR) estimates from Special Sensor Microwave Imager (SSM/I), Advanced Microwave Sounding Unit (AMSU) and daily ground-based rainfall data [32]. The daily rainfall estimates were merged by an all satellite data which were combined using the maximum likelihood estimation method and Global Telecommunication Station (GTS) data which was used to remove the bias. For regions in which rainfall was due to orographic lifting, the rain rate was estimated using a process which combined the wind direction, relative humidity and the terrain slope to produce a final estimate of total accumulated rainfall ([8] and also references therein). The FEWS-RFE is freely available on the internet through the United States Geological Survey (USGS) EROS Data Center and Climate Prediction Center (CPC). For this paper, $0.1^{\circ} \times 0.1^{\circ}$ gridded FEWS-RFE estimates were re-gridded into $0.25^{\circ} \times 0.25^{\circ}$ dataset to enhance easy comparison.

\section{Methodology}

\subsection{Rainfall Averaging}

Daily rainfall measurements from nine rain gauge GMet stations and automatic rain gauges at four locations (Figure 1), were used for this study. Daily rainfall measurements were computed for each observational point using the averaging method which is given as;

$$
P_{\text {ave }}=\frac{\sum P_{i}}{N}
$$

where $P_{\text {ave }}$ is the mean rainfall for the entire area, $P_{i}$ is the rainfall at the individual stations and $N$ is the number of rain gauges.

The perfomance of the two gauge data products (ARG and SRG) used as the reference measurements for the validation was assessed by comparing these measure- 
ments from Kumasi Airport and KNUST Agromet.

Rain gauges present the most simple and direct way of measuring rainfall amounts and rates. Nonetheless, the amount of rainfall measured is most often less than the actual rainfall reaching the ground due to losses that vary depending on the type of rainfall, gauge and location. This introduces random and systematic errors, which include but are not limited to, the wind field deformation above the gauge orifice, errors due to wetting losses on the internal walls of the collector, evaporation errors from the container and sometimes mechanical errors [33].

\subsection{Statistical Approaches}

For this paper, the performance of the gauge-satellite estimates was assessed using the bias, Mean Absolute Error (MAE) and Root Mean Square Error (RMSE) given in Equations (2)-(4) (see Appendix). In addition, a validation toolbox described in Agha et al. (2011) [34] was used for a comprehensive assessment of the perfomance of both satellite products.

Quantification of rainfall products using a set of defined metrics is essential for comprehensive assessment of uncertainties. The metrics serve as important benchmarks for measuring how well satellite-based products compare with ground- truth observations (1). The probability tests described in Agha et al. (2011) [34] [35], which include Probability of Detection (POD), False Alarm Ratio (FAR), Critical Success Index (CSI), Volumetric Hit Index (VHI), Volumetric False Alarm Ratio (VFAR), and Volumetric Miss Index (VMI) were employed for comprehensive uncertainty assessment. Probability Of Detection (POD) measures the fraction of gauge observations that are correctly detected in the satellite estimates [34] [35]. POD is sensitive to only missed events and not false alarms. Hence, it can be increased by giving out a large number of forecasts assuming that a greater number of them will be correct, usually at the expense of more false alarms. POD values range from 0 (no skill) to 1 (perfect skill).

The False Alarm Ratio (FAR) is the fraction of events observed by satellite but not confirmed by gauge observations [34] [35]. It is sensitive to false predictions only and not to missed events and ranges from 0 (perfect skill) to 1 (no skill). Critical Success Index (CSI) is also a relative measure of accuracy which is sensitive to both false alarms and missed events and ranges from 0 (no skill) to 1 (perfect skill). The Volumetric Hit Index (VHI) gives information on the fraction of the volume of rainfall that is detected correctly whereas Volumetric Miss Index (VMI) is the ratio of the volume of missed satellite estimates relative to the ground observations. They both range from 0 (no skill) to 1 (perfect skill). Volumetric False Alarm Ratio (VFAR) shows the volume of false satellite estimates above the threshold relative to the sum of the gauge observations, and also ranges from 0 (perfect skill) to 1 (no skill). Volumetric Critical Success Index (VCSI) is also a general measure of volumetric performance, ranging from 0 (no skill) to 1 (perfect score). Equations for the defined metrics are shown in the Appendix. 


\section{Results and Discussion}

\subsection{Gauge-Gauge Inter-Comparison}

Error analysis carried out for the ARG found negligible systematic and random errors which were mostly less than $0.4 \mathrm{~mm}$ at both stations for the four years. As a first step performance assessment of the new ARGs, a gauge-gauge inter-comparison was carried out using Pearson's correlation [5] [25], which showed a very good agreement with coefficient of 0.99 (see Figure 2). The SRG and ARG were at the same location, which explains the high correlation found in the gauge-gauge inter-comparison.

\subsection{Automatic Rain Gauge, TRMM and FEWS-RFE Comparison}

Figure 3 and Figure 4 show the monthly time series comparison of rainfall for gauge, TRMM and FEWS. In most cases, TRMM underestimated rainfall and FEWS-RFE sometimes overestimates the gauge rainfall values. The seasonal and annual average rainfall are shown in Figure 5 and Figure 6. In general, both wet and dry spells were clearly captured in gauge and satellite estimates as shown in Figure 5 and Figure 6. Also, the onset and cessation of the rainy season in March and November respectively [25] were well captured. Figure 7 and Figure 8 display the scatter plots of rainfall for the QWeCI and DACCIWA sites respectively. In Figure 7 it was clearly shown that there is a consistent agreement between gauge and the satellite estimates. On the other hand, Figure 8 sometimes shows a high variability between gauge and satellite rainfall measurements which could be due to the limited number of rain gauges within the study area. In addition, the difference in rainfall detection capabilities of satellites, for
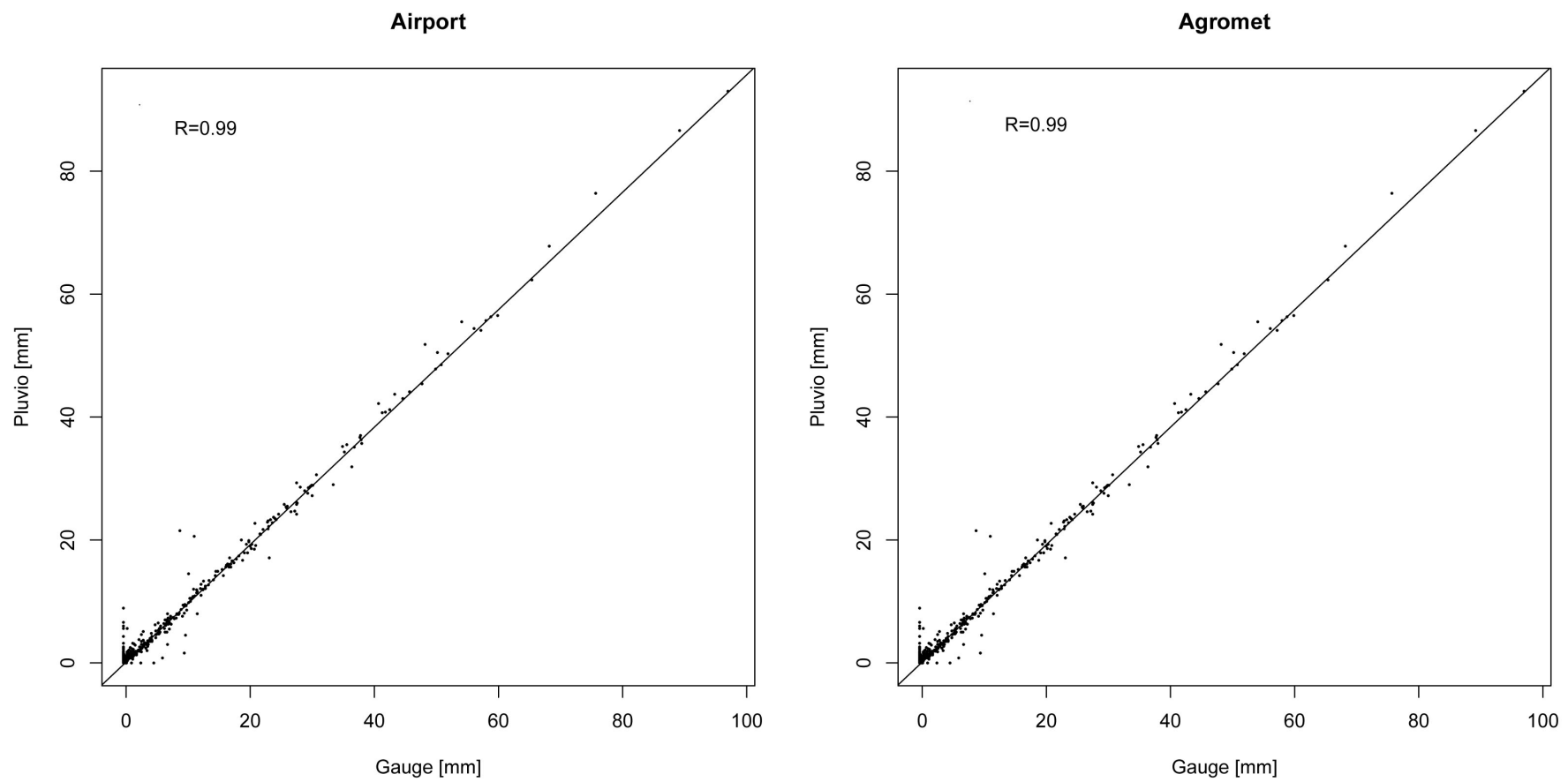

Figure 2. 4-year daily correlation plots for Kumasi Airport and KNUST Agromet. 


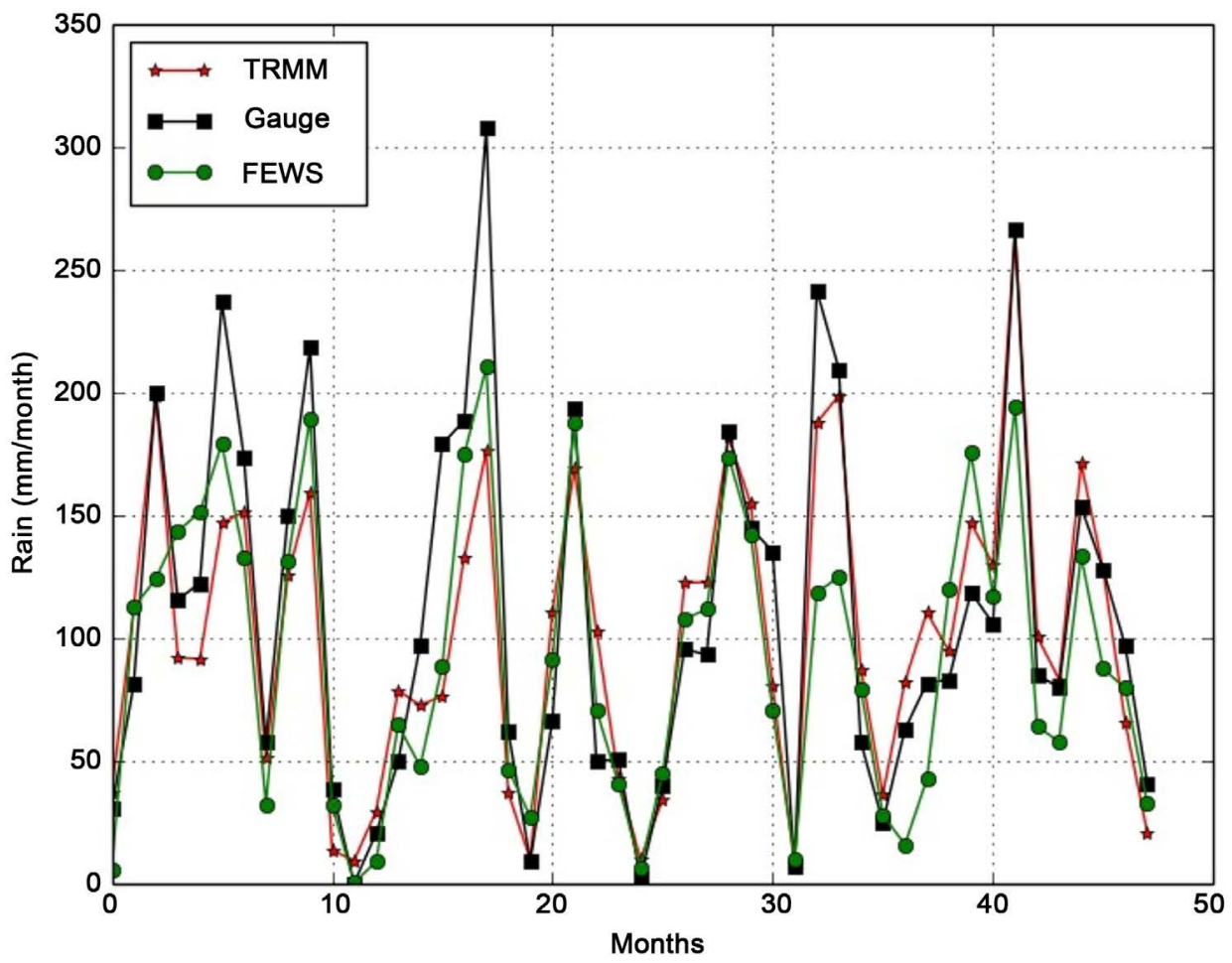

Figure 3. Monthly time series of rainfall for the various data used from 2011 to 2014: TRMM (red), FEWS-RFE (green) and gauge (black).

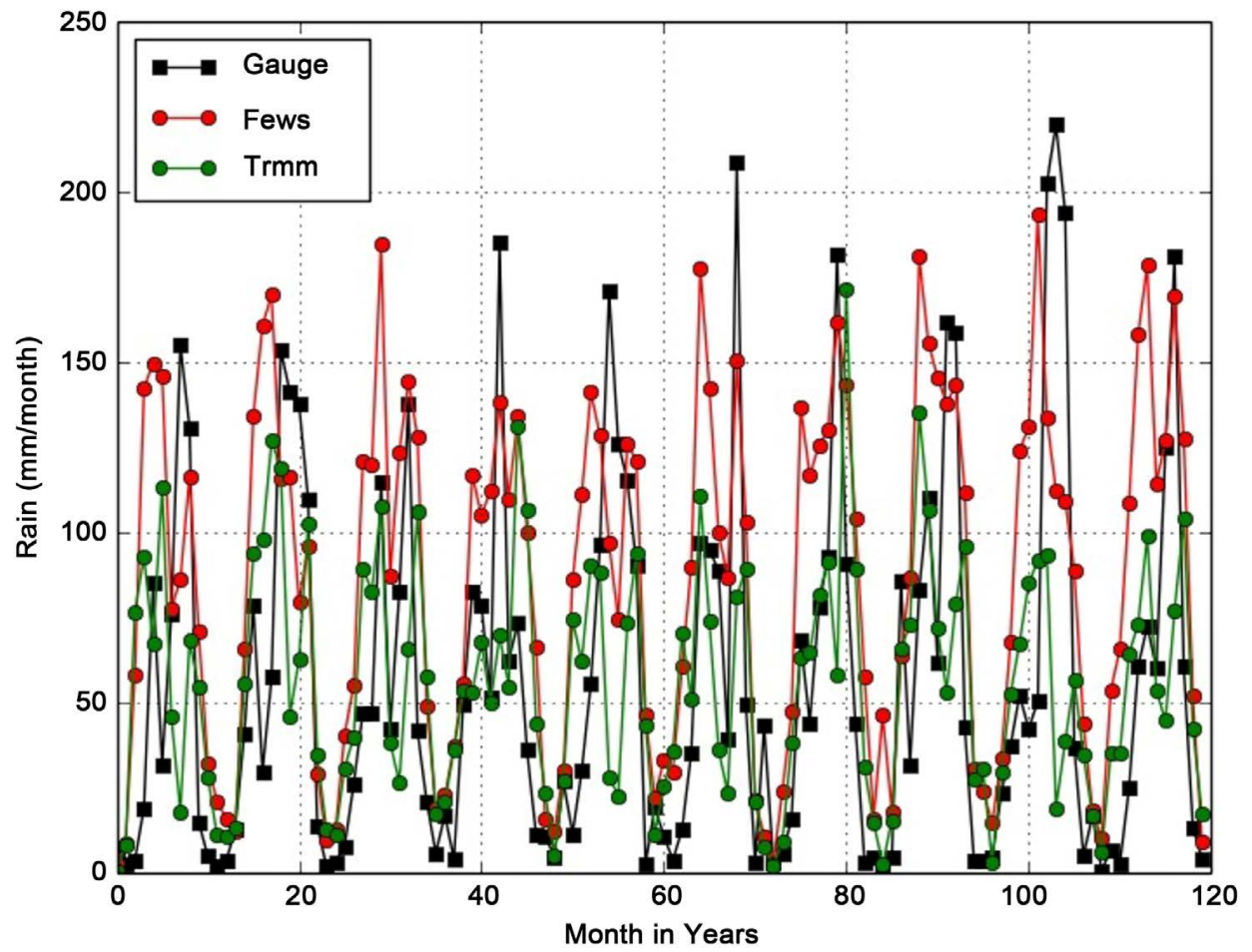

Figure 4. Monthly time series of rainfall for the various data used from 2001 to 2010: TRMM (green), FEWS-RFE (red) and gauge (black) over the region. 

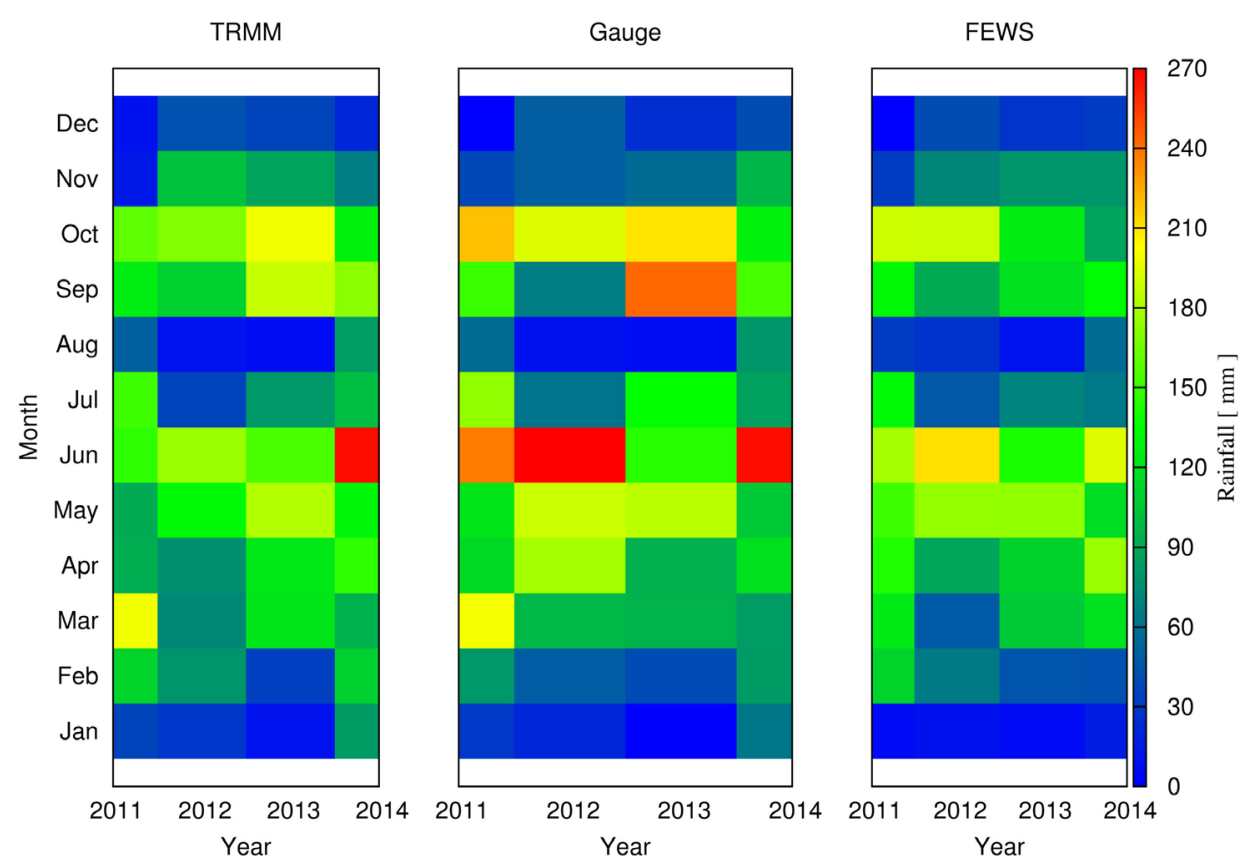

Figure 5. Seasonal and annual rainfall from 2011 to 2014: TRMM (left), FEWS-RFE (right) and gauge (center).
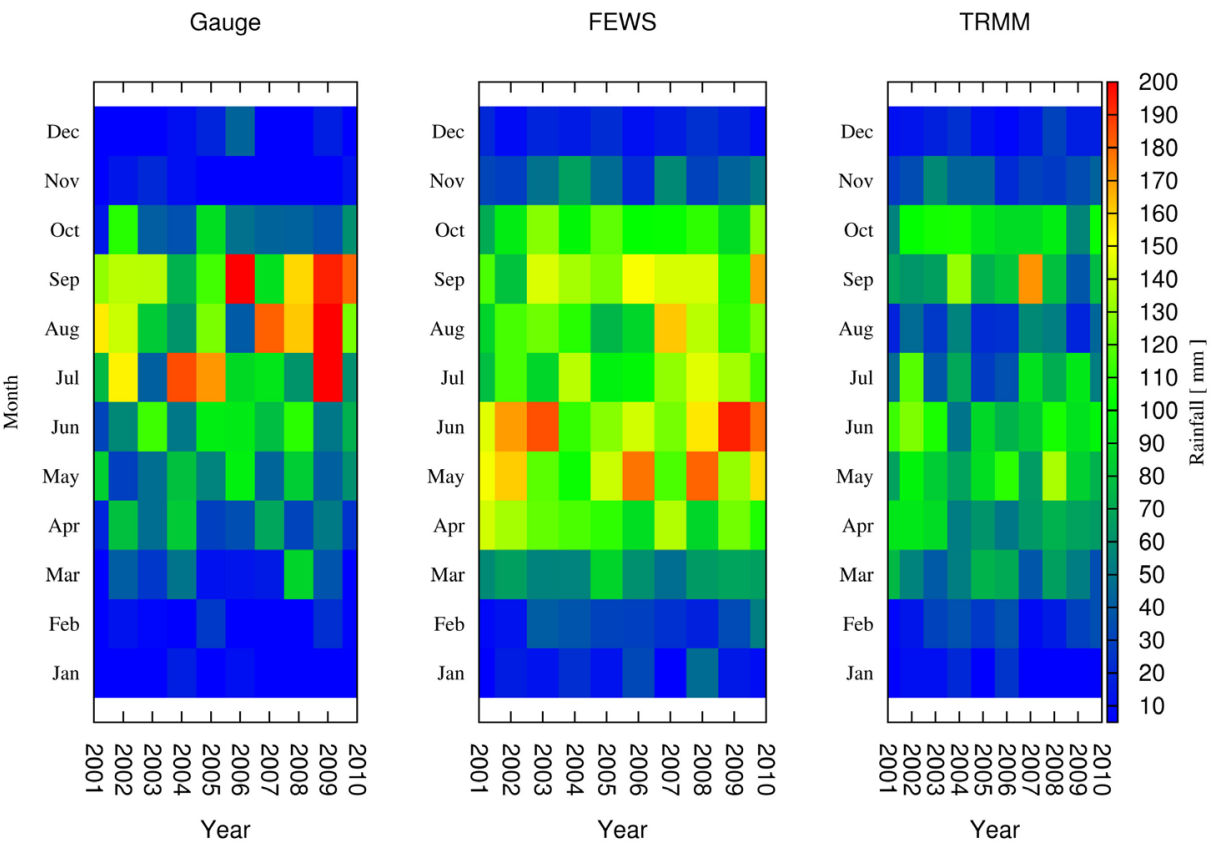

Figure 6. Seasonal and annual rainfall from 2001 to 2010: TRMM (Right), FEWS-RFE (center) and gauge (left).

example, according to (Young et al. (2014) [35] and also references therein), is that satellites are able to detect rainfall more efficiently from cold clouds than warm clouds. Good agreement seen between satellite products and gauge observations during the dry period could mostly be attributed to rainfall from cold clouds that are restricted to light 


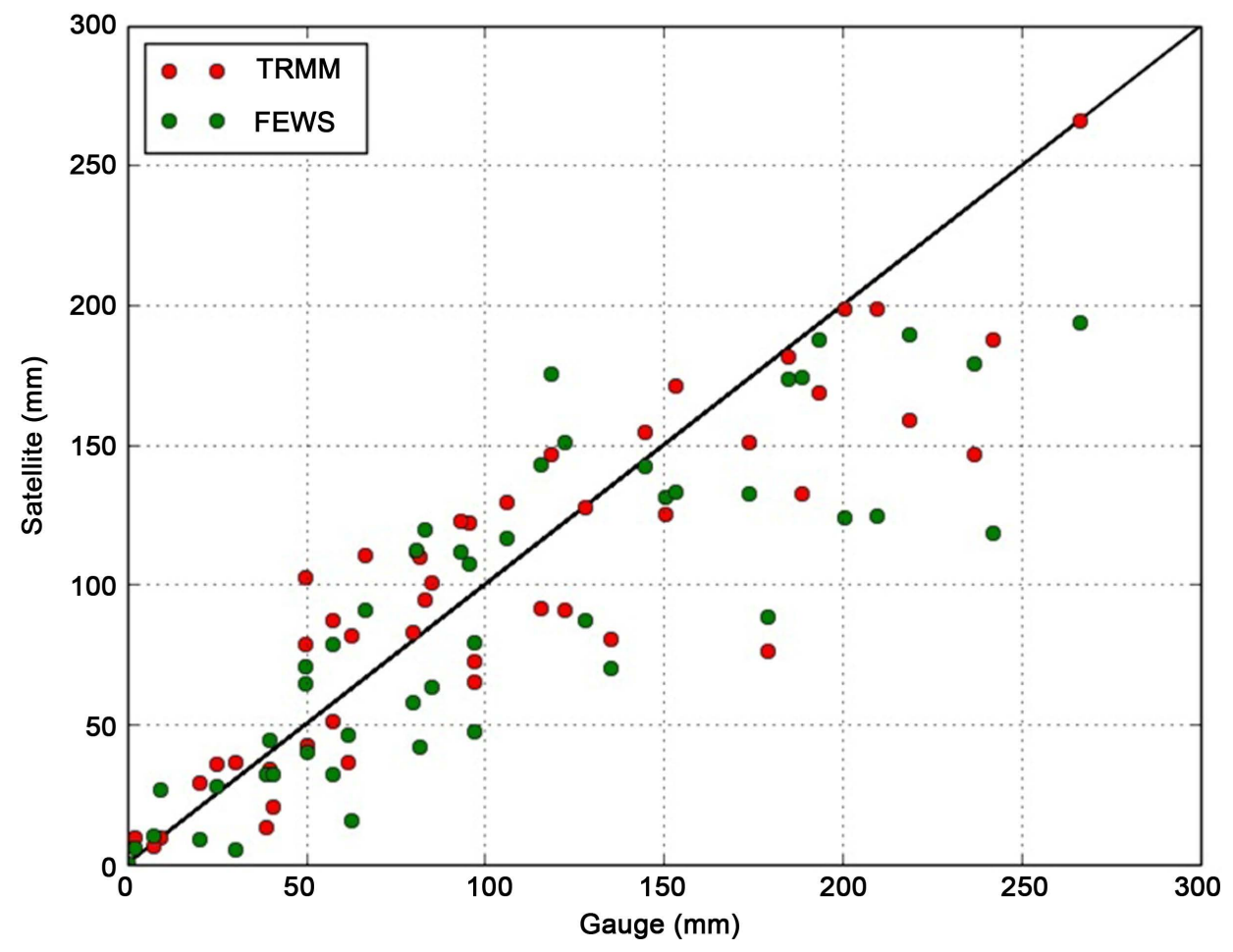

Figure 7. Scatter plot for satellite TRMM (red) and FEWS-RFE (green) measurement respect to gauge for 2011 to 2014 .

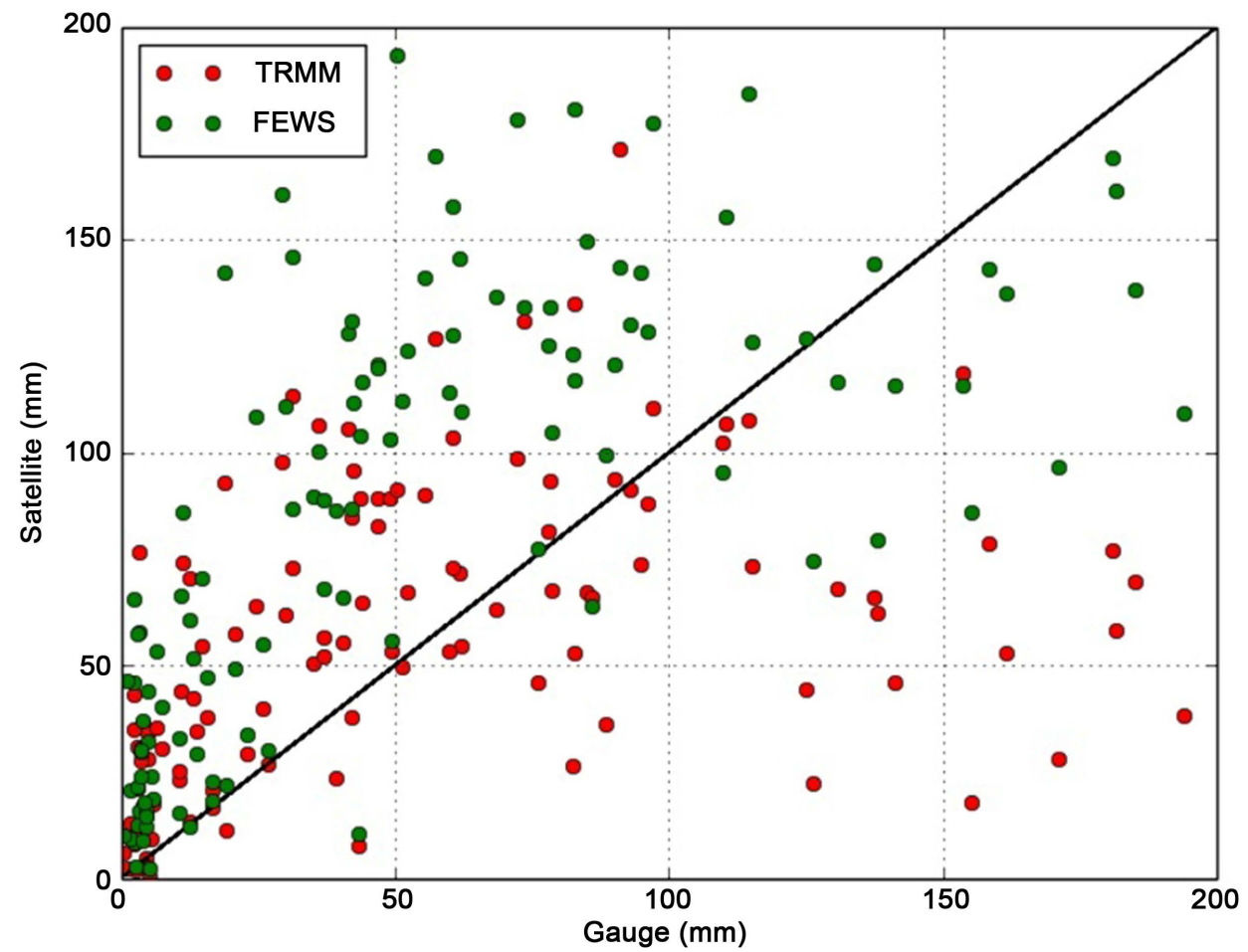

Figure 8. Scatter plot for satellite measurement TRMM (red) and FEWS-RFE(green) with respect to Gauge for 2001 to 2014 . 
rains. The accurate detection of light rainfall events by different satellite products has been previously reported ([12] and also references therein).

The correlation coefficients, which measure the linear relationship between satellite products and gauge observations were found to be 0.6 and 0.7 for FEWS-RFE and TRMM with SRG, and 0.87 and 0.86 for TRMM and FEWS with ARG respectively. The biases were less than 1.3 and 0.9 for TRMM and FEWS-RFE respectively. The RMSEs were less $10 \mathrm{~mm}$ and MAEs less than $1.0 \mathrm{~mm}$ for both satellite products (Table 1 and Table 2).

Table 1. Summary of statistics indicating the performance of TRMM comparison with Gauge for the entire study region.

\begin{tabular}{cccccccccccc}
\hline Year & Bias & $\begin{array}{l}\text { RMSE } \\
(\mathrm{mm})\end{array}$ & $\begin{array}{l}\text { MAE } \\
(\mathrm{mm})\end{array}$ & POD & VHI & FAR & VFAR & CM & VMI & CSI & VCSI \\
\hline 2001 & 1.291 & 6.420 & 0.960 & 0.940 & 0.997 & 0.357 & 0.121 & 0.060 & 0.003 & 0.618 & 0.877 \\
2002 & 1.290 & 10.860 & 1.270 & 0.970 & 0.980 & 0.418 & 0.112 & 0.030 & 0.020 & 0.571 & 0.872 \\
2003 & 1.360 & 7.680 & 1.290 & 0.951 & 0.997 & 0.373 & 0.114 & 0.049 & 0.003 & 0.607 & 0.883 \\
2004 & 1.479 & 9.400 & 1.690 & 0.977 & 0.999 & 0.332 & 0.082 & 0.023 & 0.001 & 0.658 & 0.917 \\
2005 & 1.338 & 9.770 & 1.140 & 0.960 & 0.985 & 0.314 & 0.078 & 0.040 & 0.015 & 0.667 & 0.909 \\
2006 & 1.083 & 9.600 & 0.360 & 0.924 & 0.976 & 0.256 & 0.082 & 0.076 & 0.024 & 0.701 & 0.897 \\
2007 & 1.262 & 9.750 & 0.670 & 0.954 & 0.989 & 0.330 & 0.093 & 0.046 & 0.011 & 0.649 & 0.898 \\
2008 & 1.284 & 11.380 & 1.220 & 0.968 & 0.986 & 0.339 & 0.092 & 0.032 & 0.014 & 0.647 & 0.896 \\
2009 & 1.047 & 9.190 & 0.190 & 0.939 & 0.985 & 0.291 & 0.062 & 0.061 & 0.015 & 0.678 & 0.925 \\
2010 & 1.206 & 9.480 & 0.760 & 0.969 & 0.994 & 0.294 & 0.095 & 0.031 & 0.006 & 0.691 & 0.900 \\
Mean & 1.264 & 7.340 & 0.960 & 0.955 & 0.989 & 0.330 & 0.093 & 0.045 & 0.011 & 0.649 & 0.897 \\
\hline
\end{tabular}

Table 2. Summary of statistics indicating the performance of FEWS-RFE comparison with Gauge for the entire study region.

\begin{tabular}{cccccccccccc}
\hline Year & Bias & $\begin{array}{c}\text { RMSE } \\
(\mathrm{mm})\end{array}$ & $\begin{array}{c}\text { MAE } \\
(\mathrm{mm})\end{array}$ & POD & VHI & FAR & VFAR & CM & VMI & CSI & VCSI \\
\hline 2001 & 0.896 & 5.630 & 0.340 & 0.920 & 0.985 & 0.337 & 0.093 & 0.080 & 0.015 & 0.627 & 0.895 \\
2002 & 0.706 & 7.890 & 1.280 & 0.970 & 0.994 & 0.355 & 0.097 & 0.030 & 0.006 & 0.632 & 0.898 \\
2003 & 0.840 & 5.300 & 0.570 & 0.980 & 0.998 & 0.358 & 0.100 & 0.020 & 0.002 & 0.634 & 0.899 \\
2004 & 0.829 & 6.590 & 0.580 & 0.991 & 0.998 & 0.319 & 0.110 & 0.009 & 0.002 & 0.677 & 0.888 \\
2005 & 0.915 & 4.970 & 0.280 & 0.933 & 0.993 & 0.323 & 0.176 & 0.067 & 0.007 & 0.646 & 0.819 \\
2006 & 0.717 & 5.240 & 1.180 & 0.916 & 0.935 & 0.299 & 0.208 & 0.084 & 0.065 & 0.659 & 0.750 \\
2007 & 0.810 & 6.060 & 1.340 & 0.949 & 0.969 & 0.330 & 0.184 & 0.051 & 0.031 & 0.647 & 0.798 \\
2008 & 0.797 & 7.070 & 0.840 & 0.972 & 0.951 & 0.327 & 0.338 & 0.028 & 0.049 & 0.660 & 0.640 \\
2009 & 0.753 & 5.620 & 1.010 & 0.935 & 0.939 & 0.333 & 0.281 & 0.065 & 0.061 & 0.637 & 0.686 \\
2010 & 0.837 & 5.760 & 0.630 & 0.925 & 0.925 & 0.317 & 0.253 & 0.075 & 0.075 & 0.647 & 0.705 \\
Mean & 0.810 & 7.340 & 0.820 & 0.949 & 0.969 & 0.330 & 0.184 & 0.051 & 0.031 & 0.647 & 0.798 \\
\hline
\end{tabular}


The performance of satellite products against rain gauge observations is shown in Table 1 and Table 2. The sparse nature of the rain gauge network in the region was a disadvantage for providing the categorical matrices for each of the 6 grid cells over the study region hence, mean values for each year were used (Table 1 and Table 2). Probability Of Detection (POD) which measures the fraction of gauge observations that are correctly detected in the satellite was found to be mostly greater than 0.9 . Similarly, the fraction of the volume of rainfall that is detected correctly, HI, was greater than 0.9, indicating a high rainfall detection capability of both satellite products. Furthermore, the high detection capabilities were confirmed by the low VFAR (less than 0.2 ) and very low VIM (less than 0.05) for all years. Critical Success Index (SCI) and Volumetric Critical Success Index (VCSI) were respectively greater than 0.6 and 0.8 for both satellite products.

The study found that, TRMM and FEWS-REF sometimes underestimate the observed rainfall values by at least $30 \%$ and $20 \%$ respectively. TRMM and FEWS-REF had reasonably high rainfall detection capabilities relative to gauge as evident in the POD, HI and SCSI in Table 1 and Table 2. FAR and VFAR values were low for both TRMM and FEWS-REF, indicating that very few rainfall events were captured by the satellites and not necessarily the gauge. This could be attributed to random and systematic errors associated with the satellite products including (but not limited to), its inability to capture extreme events due to its polar orbiting, sampling frequency [36], non-uniform field of view of sensors [37], the diurnal cycle of rainfall [17] and the uncertainties in the rainfall retrieval algorithms [14] [23]. Nicholson et al., 2003 [3] observed that gauge biases are usually smaller compared to biases in the satellite estimates.

\section{Conclusions}

Microscale validation of TRMM and FEWS satellite estimates with automatic rain gauge measurements have been carried out over Ashanti region of Ghana. First intercomparison between ARG and GMet SRG measurements was performed, showing a good agreement with correlation of 0.99 , which was an indication that both gauges provided consistent rainfall measurements over the period under study. Gauge satellite validation results showed good agreement with correlation coefficients of 0.6 and 0.7 for TRMM and FEWS with SRG, and 0.87 and 0.86 for TRMM and FEWS with ARG respectively. Although the Pearson correlation values are relatively high, there is an evidence of a slight under/over estimation of rainfall over the study period. This is likely attributable to the sparse gauge network over the study area or atmospheric sampling errors associated with satellite estimates.

Probability of Detection (POD) and Volumetric Hit Index (VHI) were found to be greater than 0.9. The Volumetric Critical Success Index (VCSI) was 0.9 and 0.8 respectively for TRMM and FEWS with low False Alarm Ratio (FAR) and insignificant Volumetric Miss Index (VMI). This is an indication that rainfall events were well captured by both satellite products, with few misses. In general, relatively low biases 
and RMSE values were observed for all years. Consistently, biases were below 1.3 and 0.8 for TRMM and FEWS-RFE respectively, implying a possibility for overestimation of average rainfall by at least $30 \%$ when using TRMM and underestimation by $20 \%$ when using FEWS-RFE products. Furthermore, there were very good rainfall events and volume detection capabilities by both TRMM and FEWS-RFE, relative to gauge. In addition, rainfall onsets, peaks and cessations as well as the dry spells were well captured in TRMM and FEWS-RFE, relative to gauge. Although TRMM and FEWSRFE sometimes under/overestimated rainfall in the study area, these satellite products have shown good potential for use in agricultural and other hydro-climatic impact studies.

Within the DACCIWA work project, 17 portable optical rain gauges with a minute resolution have been deployed over the Ashanti region, Ghana since June 2015. The DACCIWA gauge network is expected to provide high quality rainfall data over the study region. Hence, this rainfall dataset will improve our understanding on the rainfall types, enhance satellite validation and serve as useful database for future climatic studies.

\section{Acknowledgements}

We are thankful to Mr. Elvis Agypong for data downloading and regular maintenance of the project field sites. The research leading to these results has received funding from the European Union 7th Framework Programme (FP7/2007-2013) under Grant Agreement No. 603502 (EU project DACCIWA: Dynamics-aerosol-chemistry-cloud interactions in West Africa)

\section{References}

[1] Sorooshian, S., AghaKouchak, A., Arkin, P., Eylander, J., Foufoula-Georgiou, E., Harmon, R., Hendrickx, J., Imam, B., Kuligowski, R., Skahill, B. and Skofronick-Jackson, G. (2011) Advanced Concepts on Remote Sensing of Precipitation at Multiple Scales. Bulletin of the American Meteorological, 92, 1353-1357. http://dx.doi.org/10.1175/2011BAMS3158.1

[2] Dinku, T., Ceccato, P., Grover-Kopec, E., Lemma, M., Connor, S. and Ropelewski, C. (2007) Validation of Satellite Rainfall Products over East Africa's Complex Topography. International Journal of Remote Sensing, 28, 1503-1526. http://dx.doi.org/10.1080/01431160600954688

[3] Nicholson, S., Some, B., McCollum, J., Nelkin, E., Klotter, D., Berte, Y., Diallo, B., Gaye, I., Kpabeba, G., Ndiaye, O., Noukpozounkou, J., Tanu, M., Thiam, A., Toure, A. and Traore, A. (2003) Validation of TRMM and Other Rainfall Estimates with a High-Density Gauge Dataset for West Africa. Part I: Validation of GPCC Rainfall Product and Pre-TRMM Satellite and Blended Products. Journal of Applied Meteorology, 42, 1337-1354. http://dx.doi.org/10.1175/1520-0450(2003)042<1337:VOTAOR>2.0.CO;2

[4] Owusu, K. and Waylen, P. (2012) The Changing Rainy Season Climatology of Mid-Ghana. Theoretical and Applied Climatology, 112, 419-430.

[5] Manzanas, R., Amekudzi, L., Preko, K., Herrera, S. and Gutierrez, J. (2014) Precipitation Variability and Trends in Ghana: An Intercomparison of Observational and Reanalysis Products. Climatic Change, 124, 805-819. 
[6] Lin, X., Fowler, L. and Randall, D. (2002) Flying the TRMM Satellite in a General Circulation Model. Journal of Geophysical Research, 107, ACH 4-1-ACH 4-17.

[7] Herman, A., Kumar, V., Arkin, P.A. and Kousky, J.V. (1997) Objectively Determined 10Day African Rainfall Estimates Created for Famine Early Warning. International Journal of Remote Sensing, 18, 2147-2159. http://dx.doi.org/10.1080/014311697217800

[8] Symeonakis, E., Bonifacio, R. and Drake, D. (2008) Validation of Satellite and Rain-Gauge Data for Parameterising a Soil Erosion Model for Sub-Saharan Africa. International Archives of Photogrammetry and Remote Sensing, XXXIII, 215-222.

[9] Wolff, D.B. and Fisher, B.L. (2007) Comparison of Instantaneous TRMM Satellite and Ground Validation Rain Rate Estimates. 33rd Conference on Radar Meteorology, Cairns, 6-10 August 2007.

[10] Hermann, S., Anyamba, A. and Tucker, C. (2005) Recent Trends in Vegetation Dynamics in the African Sahel and Their Relationship to Climate. Global Environmental Change, 15, 394-404. http://dx.doi.org/10.1016/j.gloenvcha.2005.08.004

[11] Zhou, T., Yu, R., Chen, H., Dai, A. and Pan, Y. (2008) Summer Precipitation Frequency, Intensity and Diurnal Cycle over China: A Comparison of Satellite Data with Rain Gauge Observations. Journal of Climate, 21, 3997-4010. http://dx.doi.org/10.1175/2008JCLI2028.1

[12] Thiemig, V., Rojas, R., Zambrano-Bigiarini, M., Levizzani, V. and De Roo, A. (2012) Validation of Satellite-Based Precipitation Products over Sparsely Gauged African River Basins. Journal of Hydrometeorology, 13, 1760-1783. http://dx.doi.org/10.1175/JHM-D-12-032.1

[13] Zhao, T. and Yatagai, A. (2014) Evaluation of TRMM 3 B42 Product Using a New GaugeBased Analysis of Daily Precipitation over China. International Journal of Climatology, 34, 2749-2762. http://dx.doi.org/10.1002/joc.3872

[14] Maggioni, V., Meyers, P.C. and Robinson, M.D. (2016) A Review of Merged High-Resolution Satellite Precipitation Product Accuracy during the Tropical Rainfall Measuring Mission (TRMM) Era. Journal of Hydrometeorology, 17, 1101-1117. http://dx.doi.org/10.1175/JHM-D-15-0190.1

[15] Yong, B., Ren, L.-L., Hong, Y., Wang, J.-H., Gourley, J., Jiang, S.-H., Chen, X. and Wang, W. (2010) Hydrologic Evaluation of Multisatellie Precipitation Analysis Standard Precipitation Products in Basins beyond Its Inclined Latitude Band: A Case Study in Laohahe Basin, China. Water Resources Research, 46. http://dx.doi.org/10.1029/2009WR008965

[16] Tompkins, A.M. and Adebiyi, A.A. (2012) Using CloudSat cloud Retrieval to Differentiate Satellite-Derived Rainfall Products over West Africa. Journal of Hydrometeorology, 13, 1810-1816. http://dx.doi.org/10.1175/JHM-D-12-039.1

[17] Moazami, S., Golian, S., Kavianpour, M. and Hong, Y. (2013) Comparison of PERSIANN and V7 TRMM Multisatellite Precipitation Analysis (TMPA) Products with Rain Gauge Data over Iran. International Journal of Remote Sensing, 34, 8156-8171. http://dx.doi.org/10.1080/01431161.2013.833360

[18] As-Syakur, A., Tanaka, T., Prasetia, R., Swardika, I. and Kasa, I. (2011) Comparison of TRMM Multisatellite Precipitation Analysis (TMPA) Products and Daily-Monthly Gauge Data over Bali. International Journal of Remote Sensing, 32, 8969-8982. http://dx.doi.org/10.1080/01431161.2010.531784

[19] Liu, J., Duan, Z., Jiang, J. and Zhu, A.-X. (2015) Evaluation of Three Satellite Precipitation Products TRMM 3B42, CMORPH, and PERSIANN over a Subtropical Watershed in China. Advances in Meteorology, 201, 1-14.

[20] Nair, S., Srinivasan, G. and Nemani, R. (2009) Evaluation of Multi-Satellite TRMM Derived Rainfall Estimates over a Western State of India. Journal of the Meteorological Society of 
Japan, 87, 927-939. http://dx.doi.org/10.2151/jmsj.87.927

[21] Haque, R., Maskey, S., Uhlenbrook, S. and Mull, M. (2013) Validation of TRMM Rainfall for Pangani River Basin in Tanzania. Journal of Hydroloy and Environmental Research, 1, $30-40$.

[22] Friesen, J. and Diekkriuger, B. (2002) Spatio-Temporal Rainfall Patterns in the Northern Ghana. Diplom Thesis, Geographische Institute der Rheinischen Friedrich-Wilhelms, University at Bonn, Bonn.

[23] Novella, N. and Thiaw, W. (2012) African Rainfall Climatology Version 2 for Famine Early Warning Systems. Journal of Applied Meteorology and Climatology, 52, 588-606. http://dx.doi.org/10.1175/JAMC-D-11-0238.1

[24] Knippertz, P., Coe, H., Chiu, C., Evans, M.J., Fink, A.H., Kaltho, N., Liousse, C., Mari, C., Allan, R., Brooks, B., et al. (2015) The DACCIWA Project: Dynamics-Aerosol-ChemistryCloud Interactions in West Africa. Bulletin of the American Meteorological Society. http://dx.doi.org/10.1175/BAMS-D-14-00108.1

[25] Amekudzi, L., Yamba, E., Preko, K., Asare, E., Aryee, J., Baidu, M. and Codjoe, S. (2015) Variabilities in Rainfall Onset, Cessation and Length of Rainy Season for the Various AgroEcological Zones of Ghana. Entropy, 3, 416-434. http://dx.doi.org/10.3390/cli3020416

[26] Sylla, M., Diallo, I. and Pal, J. (2013) West African Monsoon in State-of-the-Science Regional Climate Models. In: Tarhule, A., Ed., Climate Variability-Regional and Thematic Patterns, InTech, Vol. 10, 55140.

[27] Dong, X., Dohmen-Janssen, C. and Booij, J. (2005) Appropriate Spatial Sampling of Rainfall for Ow Simulation. Hydrological Sciences Journal, 50, 279-298. http://dx.doi.org/10.1623/hysj.50.2.279.61801

[28] GmbH, O.M. and KG, C. (1999) Getting Started HYDRAS 3: Application Software for Hydrology, Meteorology and Environmental Protection. Ludwigstrasse 16 D-87437 Kempten.

[29] Kummerow, C., Barnes, W., Kozu, T., Shiue, J. and Simpson, J. (1998) The Tropical Rainfall Measuring MIssion (TRMM) Sensor Package. Journal of Atmospheric and Oceanic Technology, 15, 809-817. http://dx.doi.org/10.1175/1520-0426(1998)015<0809:TTRMMT>2.0.CO;2

[30] Human, G. and Bolvin, D. (2014) TRMM and Other Data Precipitation Dataset Documentation. Technical Report, Mesoscale Atmospheric Processes Laboratory, NASA Goddard Space Flight Center and Science Systems and Applications Inc. http://dx.doi.org/10.1175/1520-0426(1998)015<0809:TTRMMT>2.0.CO;2

[31] Xue, X., Hong, Y., Limaye, A., Gourley, J., Human, G., Khan, S., Dorji, C. and Chen, S. (2013) Statistical and Hydrological Evaluation of TRMM-Based Multisatellite Precipitation Analysis over the Wangchu Basin of Bhutan: Are the Latest Satellite Precipitation Products 3B42V7 Ready for Use in Ungauged Basins? Journal of Hydrology, 499, 91-99. http://dx.doi.org/10.1016/j.jhydrol.2013.06.042

[32] Tote, C., Patricio, D., Boogaard, H., van der Wijngaart, R., Tarnavsky, E. and Funk, C. (2015) Evaluation of Satellite Rainfall Estimates for Drought and Flood Monitoring in Mozambique. Journal of Remote Sensing, 7, 1758-1776. http://dx.doi.org/10.3390/rs70201758

[33] Wagner, A. (2009) Literature Study on the Correction of Precipitation Measurements. FutMon C1-Met-29 (BY), Bavarian State Institute of Forestry, Freising.

[34] AghaKouchak, A., Behrangi, A., Sorooshian, S., Hsu, K. and Amitai, E. (2011) Evaluation of Satellite-Retrieved Extreme Precipitation Rates across the Central United States. Journal of Geophysical Research, 116, Article ID: D02115. http://dx.doi.org/10.1029/2010jd014741

[35] Young, M.P., Williams, C.J., Chiu, J.C., Maidment, R.I. and Chen, S.-H. (2014) Investiga- 
tion of Discrepancies in Satellite Rainfall Estimates over Ethiopia. Journal of Hydrometeorology, 15, 2347-2369. http://dx.doi.org/10.1175/JHM-D-13-0111.1

[36] Fisher, B. and Wol, D. (2010) Satellite Sampling and Retrieval Errors in Regional Monthly rain Estimates from TMI AMSR-E, SSM/I, AMSU-B and the TRMM PR. Journal of Applied Meteorology and Climatology, 50, 994-1023. http://dx.doi.org/10.1175/2010JAMC2487.1

[37] Graves. C.E. (1993) A Model for the Beam-Filling Effect Associated with Microwave Retrieval of Rain. Journal of Atmospheric and Ocean Technology, 10, 5-10.

http://dx.doi.org/10.1175/1520-0426(1993)010<0005:AMFTBF>2.0.CO;2 


\section{Appendix}

$$
\begin{gathered}
\text { Bias }=\frac{\sum_{i=1}^{n}\left(T_{i}\right)}{\sum_{i=1}^{n}\left(G_{i}\right)} \\
\text { MAE }=\frac{1}{n} \sum_{i=1}^{n}\left|\left(T_{i}-G_{i}\right)\right| \\
\text { RMSE }=\sqrt{\frac{1}{n} \sum_{i=1}^{n}\left(T_{i}-G_{i}\right)^{2}}
\end{gathered}
$$

Pearson's Correlation Co-efficient:

$$
r_{T G}=\frac{\sum_{i=1}^{N}\left(T_{i}-\mu_{T}\right)\left(G_{i}-\mu_{G}\right)}{(N-1) \sigma_{T} \sigma_{G}}
$$

where $T_{i}$ is the satellite estimates and $G_{i}$ is the gauge measurement, $\mu$ is the arithmetic mean, $\sigma$ is the standard deviation and $r_{T G}$ is the Pearson Correlation Coefficient $(r \in-1,1)$.

Probability Of Detection (POD) is given as

$$
\mathrm{POD}=\frac{H}{H+M} .
$$

False Alarm Ratio (FAR) is given as

$$
\mathrm{FAR}=\frac{F}{H+F} .
$$

Critical Success Index (CSI) is given as

$$
\mathrm{CSI}=\frac{H}{H+F+M} .
$$

Volumetric Hit Index (VHI) is given as

$$
\mathrm{VHI}=\frac{\sum_{i=1}^{n}\left(P_{\text {sat }} \mid P_{\text {sat }} \geq t \& P_{\text {ref }} \geq t\right)}{\sum_{i=1}^{n}\left(P_{\text {sat }} \mid P_{\text {sat }} \geq t \& P_{\text {ref }} \geq t\right)+\sum_{i=1}^{n}\left(P_{\text {ref }} \mid P_{\text {sat }} \geq t \& P_{\text {ref }} \geq t\right)}
$$

Volumetric False Alarm Ratio (VFAR) is given as

$$
\text { VFAR }=\frac{\sum_{i=1}^{n}\left(P_{\text {sat }} \mid P_{\text {sat }} \geq t \& P_{\text {ref }}<t\right)}{\sum_{i=1}^{n}\left(P_{\text {sat }} \mid P_{\text {sat }} \geq t \& P_{\text {ref }} \geq t\right)+\sum_{i=1}^{n}\left(P_{\text {ref }} \mid P_{\text {sat }} \geq t \& P_{\text {ref }}<t\right)}
$$

Volumetric Miss Index (VMI) is given as

$$
\mathrm{VMI}=\frac{\sum_{i=1}^{n}\left(P_{\text {ref }} \mid P_{\text {sat }} \leq t \& P_{\text {ref }}>t\right)}{\sum_{i=1}^{n}\left(P_{\text {sat }} \mid P_{\text {sat }}>t \& P_{\text {ref }}>t\right)+\sum_{i=1}^{n}\left(P_{\text {ref }} \mid P_{\text {sat }} \leq t \& P_{\text {ref }}>t\right)} .
$$


Volumetric Critical Success Index (VCSI) is given as

$$
\text { VCSI }=\frac{\sum_{i=1}^{n}\left(P_{\text {sat }} \mid P_{\text {sat }}>t \& P_{\text {ref }}>t\right)}{\sum_{i=1}^{n}\left(P_{\text {sat }} \mid P_{\text {sat }}>t \& P_{r e f}>t\right)+\sum_{i=1}^{n}\left(P_{r e f} \mid P_{\text {sat }} \leq t \& P_{r e f}>t\right)+\sum_{i=1}^{n}\left(P_{\text {sat }} \mid P_{\text {sat }}>t \& P_{\text {ref }} \leq t\right)}
$$

where Hit $(\mathrm{H})$ is the rain correctly detected, Miss (M) is the rainfall observed but not detected, False (F) is the rain detected but not observed, $P_{\text {sat }}$ is the satellite estimate, $P_{\text {ref }}$ is the rain gauge measurement and $t$ is the threshold value given to be zero.

Submit or recommend next manuscript to SCIRP and we will provide best service for you:

Accepting pre-submission inquiries through Email, Facebook, LinkedIn, Twitter, etc. A wide selection of journals (inclusive of 9 subjects, more than 200 journals)

Providing 24-hour high-quality service

User-friendly online submission system

Fair and swift peer-review system

Efficient typesetting and proofreading procedure

Display of the result of downloads and visits, as well as the number of cited articles Maximum dissemination of your research work

Submit your manuscript at: http://papersubmission.scirp.org/

Or contact acs@scirp.org 